Volume 15 - Número 2 - ago/dez de 2020

\title{
READING SKILLS AND PRIOR KNOWLEDGE IN THE COMPREHENSION OF CAUSAL RELATIONS: MULTIPLE INTERACTIONS BETWEEN FORMAL SCHOOLING, TYPE OF INFORMATION AND COHESION MARKERS
}

\section{HABILIDADES DE LEITURA E CONHECIMENTOS PRÉVIOS NA COMPREENSÃO DAS RELAÇÕES CAUSAIS: MÚLTIPLAS INTERAÇÕES ENTRE A ESCOLA FORMAL, TIPO DE INFORMAÇÃO E MARCADORES DE COESÃO}

Gabriela Mariel Zunino ${ }^{1}$

\begin{abstract}
The main objective of this paper is to analyze the interactions between reading skills, readers' prior knowledge and the linguistic characteristics of texts, specifically during the comprehension of causal relations in Spanish. Within this framework, we also attempt to provide psycholinguistic evidence that will help us understand text-based learning processes. We present two psycholinguistic experiments to analyze the link between prior knowledge and readers' formal schooling level with text variables, such as absence/ presence of connectives and the structure of causal relations during the text comprehension process. This gives us the possibility to simultaneously analyze several interactions. We evaluated response time, reading time, and accuracy in the responses. Our results show that not involving prior knowledge changes causal relations comprehension patterns, but also that in these cases, the presence of connectives not only facilitates the comprehension process but rather is a condition to make it possible. We also discuss the need to differentiate general reading skills from the area of expertise that the subjects may have, since these variables connect in specific ways with the different text types. In order to boost text-based learning processes it is necessary to display a clear range of conclusions referring to these multiple interactions.
\end{abstract}

KEYWORDS: Psycholinguistics. Text. Semantic relations. Connectives. World knowledge.

RESUMO: O objetivo principal deste artigo é analisar as interações entre as habilidades de leitura, o conhecimento prévio do leitor e as características linguísticas dos textos, especificamente durante a compreensão das relações causais em espanhol. Dentro dessa estrutura, também tentamos fornecer evidências psicolinguísticas que nos ajudarão a compreender os processos de aprendizagem baseados em texto. Apresentamos dois experimentos psicolinguísticos para analisar a ligação entre o conhecimento prévio e o nível de escolaridade formal dos leitores com variáveis textuais, como ausência / presença de conectivos e a estrutura das relações causais durante o processo de compreensão do texto. Isso nos dá a possibilidade de analisar simultaneamente várias interações. Avaliamos o tempo de resposta, o tempo de leitura e a precisão das respostas. Nossos resultados mostram que não envolver o conhecimento prévio altera os padrões de compreensão das relações causais, mas também que, nesses casos, a presença de conectivos não só facilita o processo de compreensão, mas é uma condição para torná-lo possível. Discutimos também a necessidade de diferenciar as habilidades gerais de leitura da área de conhecimento que os sujeitos podem ter, uma vez que essas variáveis se conectam de forma específica com os diferentes tipos de texto. Para impulsionar os processos de aprendizagem baseados em texto, é necessário apresentar um conjunto claro de conclusões referentes a essas múltiplas interações.

PALAVRAS-CHAVE: Psicolinguística. Texto. Relações semânticas. Conectivos. Conhecimento do mundo.

\footnotetext{
${ }^{1} \mathrm{PhD}$ in Linguistics. Researcher at Consejo Nacional de Investigaciones Científicas y Técnicas (CONICET), Argentina. Assitant Professor at Universidad de Buenos Aires (UBA), Argentina. Email: gmzunino@conicet.gov.ar. ORCID: https://orcid.org/0000-0002-0473-6192.
} 
Volume 15 - Número 2 - ago/dez de 2020

\section{Introduction}

Discourse comprehension is a complex phenomenon, involving simultaneous processing of both information at different linguistic levels and non linguistic information (GRAESSER, 1981; KINTSCH, 1988; KINTSCH, 1998; VAN DIJK; KINTSCH, 1983). Our approach to these complexities was to focus especially on causal relations, understood as those that establish a consistent text network and make it possible to build a coherent mental representation of the discourse (GERNSBACHER, 1991; GOLDMAN et al., 1999; KINTSCH, 1998; NOORDMAN; VONK, 1998; SANDERS, 2005; ZWAAN; RADWANSKY, 1998, ZUNINO, 2014; inter alia).

Within this general framework, in recent years, psycholinguistic studies have paid more attention to the role of our world knowledge during language comprehension and production. The results of many of these studies suggest that prior knowledge always has an impact on discourse processing (FRANK et al., 2003; KAMALSKI; SANDERS; LENZ, 2008; KINTSCH, 1988; KUPERBERG et al., 2006; METUSALEM et al., 2016; NOORDMAN; VONK, 1998; RAITER, 2000; ZUNINO; ABUSAMRA; RAITER, 2016). However, it is still unclear in what specific ways this information plays a role, and how it articulates with other variables, such as text structure, syntactic information, explicit semantic markers and subjects' reading skills, among others (BOSCH; SEGERS; VERHOEVEN, 2018; KAMILSKI et al., 2008; KENDEOU; VAN DEN BROEK, 2007; LINDERHOLM et al., 2000; O'REILLY; MCNAMARA, 2007a; VAN DIJK, 1992; ZUNINO, 2017).

There are several approaches to the effects of world knowledge and its conceptual organization in the mind during language processing, text comprehension, and learning. Several studies have suggested that the effect of world knowledge is decisive, especially in the most abstract level of representation: situation model ${ }^{2}$ (BEKER et al., 2017; COZJN et al., 2011, HAGOORT et al., 2004, NOORDMAN et al., 2014, O'REILLY; MCNAMARA, 2007b). Of course, world knowledge articulates, in a permanent and inevitable way, with linguistic markers present in the text, e.g., connectives with specific semantic content and structure. In addition, research has delved into the differences between the reading strategies used by expert and non expert readers - understood as those who can or cannot involve their prior knowledge during the process- which are significantly different. McNamara et al., (1996), for instance, found that expert readers -defined as those who have prior knowledge of the text topic-could benefit more from a text with fewer explicit markers, since they are capable of a more "active" reading process. Non expert readers, on the other hand, may require more connectives and other markers, as guidelines to comprehension, since for them it is more difficult to recover semantic relations based on prior knowledge. Several researchers (BEKER et al., 2017; ELBRO; BUCHIVERSEN, 2013; LINDERHOLM et al., 2000; MCNAMARA, 2001; O'REILLY; MCNAMARA, 2007a; O'REILLY; MCNAMARA, 2007b) have shown concurring evidence of what is usually called "reverse cohesion effect" and have contributed to a more accurate analysis in connection with the multiple and complex articulations between text features and readers' characteristics during comprehension and learning based on texts.

On the other hand, ZUNINO et al (2012) and ZUNINO (2014) have found evidence that the absence of prior knowledge during the comprehension process of causal and countercausal $^{3}$ relations decisively changes the processing pattern, and therefore they postulate that

${ }^{2}$ For a detailed explanation of the Construction-Integration Model, see Van Dijk and Kintsch (1983), Graesser (1981), Raiter (2003), among others.

${ }^{3}$ We understand counter-causal relations as part of the broad causal semantic/conceptual dimension, since they suspend or contradict the reader's causality expectations. Thus, the idea of counter-causality is based on the link between the reader's prior knowledge -which constitute the main support for their default causal expectations (ZUNINO, 2014)-and the information offered by the text, which may match or not match those expectations. 
Volume 15 - Número 2 - ago/dez de 2020

comprehension, in the absence of explicit linguistic markers, is greatly restricted and guided by prior knowledge.

However, it is not possible to conclude that our discourse comprehension is solely based on our prior knowledge, nor can we suggest that without it the comprehension process would be impossible. In fact, such an assumption would mean that basing learning processes on written texts is unfeasible, when it is well known that they are one of the main sources in learning, especially in formal educational environments. It is precisely in this point when the linguistic features of texts play an essential role. Given this scenario, adequately handling the semantic information contained in certain linguistic constructions or certain lexemes, such as connectives, seems to be one of the basic and essential elements for adequate discourse comprehension, and it may even be indispensable to establish relations in certain cases (BEKER et al., 2017; DEGAND et al., 1999; KAMILSKI et al., 2008; LINDERHOLM et al., 2000; MURRAY, 1997; O'REILLY; MCNAMARA, 2007a; VAN SILFHOUT; EVERSVERMEUL; SANDERS, 2015; ZUNINO et al., 2012; ZUNINO, 2014). For example, adequately interpreting the semantic value of a connective such as "because" -and the processing instruction it entails (CARON et al., 1988; HABERLANDT, 1982; KUPERBERG et al., 2011; MURRAY, 1997; SANDERS, 2005)- could surmount the obstacle inherent to the comprehension of a text/discourse that presents information completely unknown to the reader/ listener.

One option when it comes to studying these issues is to analyze comprehension in subjects with different levels of formal schooling, a factor that is associated with different levels of prior knowledge, and reading strategies (BEKER et al., 2017; BOSCH et al., 2018; ELBRO; BUCH-IVERSEN, 2013; KAMILSKI et al., 2008; LINDERHOLM et al., 2000; MCNAMARA, 2001; O'REILLY; MCNAMARA, 2007a; O'REILLY; MCNAMARA, 2007b). Our experiment 1 focuses on effects due to formal schooling. However, it is also possible to experimentally control the type of information offered to subjects with the same level of formal schooling: along these lines, we developed our Experiment 2.

This paper focuses on analyzing the different links between readers' prior knowledge and the linguistic marks such as connectives, during written text comprehension, especially regarding the causal dimension. We will also try to discuss the articulation between the psycholinguistic evidence and the possibility of enhancing learning processes on the basis of an adequate text comprehension. We believe that comprehension of the underlying (psycho)linguistic processes that are at play will be vital to discuss and enhance educational processes at all levels in different pedagogical environments.

\section{Experiment 1}

The main purpose of this experiment is to analyze if there are differences -and if any, which are these differences- between two groups of subjects with different formal schooling levels. Our assumption is that the two groups use different reading strategies and that subjects with higher schooling levels are more skilled readers than those with low schooling levels. We will pay special attention to whether the use of linguistic knowledge -connectives as semantic processing instructions-, an element a priori considered common to both groups, produces a differential effect on comprehension. In summary, we are interested in detecting interactions between subjects' reading characteristics and the characteristics of texts, specifically in the causality dimension.

Special attention was paid to the analysis of adversative constructions with "but" and concessive constructions with "although/ though", as linguistic markers of counter-causality (ZUNINO; ABUSAMRA; RAITER, 2012, ZUNINO, 2014; ZUNINO, 2016). 
A task to evaluate the comprehension of semantic relations was designed as follows: texts with two sentences, where both sentences or clauses establish a causal relation in one of two possible ways, [cause]-[effect] or [effect]-[cause]. The contribution of this paper, in connection with prior studies, is that it gives us the possibility to simultaneously analyze interactions with more than one independent variable: formal schooling level, text marker presence (connectives), and the way in which semantic relations are presented (iconicity). The concept of "iconicity" is usually linked to isomorphism, even though the overlapping is not complete. In general, it refers to the correspondence between "natural order" (facts of the world) and the "figurative order" (linguistic expression or representation). Out of the three classic principles considered in the analysis of iconicity (quantity, proximity and sequential order), the one that has been studied the most in connection with discourse comprehension is sequential order: the order of the events in the world (actual or represented) is reflected by the syntagmatic order of the clauses that verbally describe it (MARCUS; CALUDE, 2010).

Our initial predictions indicate that: a) the reverted order [effect]-[cause], due to a break in the iconicity principle (HAIMAN, 1983, MARCUS; CALUDE, 2010), may pose a processing difficulty that will be more clearly seen in the low schooling group; $b$ ) the insertion of connectives will facilitate processing in both groups, but the demand for an explicit semantic marker will be higher in the low schooling group.

\subsection{Method}

\subsubsection{Participants}

In the high schooling group, we included 46 subjects, between 23 and 61 years of age 4 -mean age: 41.15, Standard Deviation (SD): 13.98-, who are native speakers of Rio de la Plata Spanish, with 12 to 18 years of formal schooling -mean: 17.43, SD: 1.40-. In the low schooling group, we included 32 subjects, between 19 and 57 years of age (mean: 27.97, SD: 12.56), who are native speakers of Rio de la Plata Spanish, with 7 to 12 years of formal schooling-mean: 10.67, SD: 0.72-.

The participants were paired according to age, schooling level and gender, and the results were treated statistically as repeated measures, i.e., we used a matched subject design (see Gravetter \& Wallnau, 2009).

With this distribution, we obtained data from 23 high schooling subjects and 16 low schooling subjects per condition.

\subsubsection{Materials}

The items presented two clauses; in condition number 1 -no connective present-, there are two sentences, while in condition number 2 -with a connective present-, the two clauses are part of the same sentence. Each text is followed by a question with this pattern 'Does $A$ generate $B$ ?' The question always seeks to verify the establishment of the causal link between the two clauses.

The following grammatical aspects were controlled: 1) S-V-O structures were used, with one simple adjunct at the most; 2) compound sentences and constructions were avoided; 3 ) verbs always appear in indicative mode, in simple present or simple past; 4) there are no cleft sentences, subordinate adjectival clauses, adverbial subordinate clauses (except those that could

\footnotetext{
${ }^{4}$ Due to a methodological decision in terms of the possibility of generalizing our results, we decided to take a sample with an age variance broader than usual for this type of study, limiting the sample to graduate students, despite the limitation that this imposes on data generalization.
} 
correspond to the constructions studied) or nominal subordinate clauses; 5) any explicit negation was avoided, both in the items and the questions; only lexical negation was used whenever necessary.

In every case the extension of the items was controlled by number of words: 1) every item is made up of 12 to 18 words (mean $=14.3$ words per item); 2 ) all of the questions have 7 to 12 words (mean $=9.4$ words per question).

We also balanced out the 'time' variable -tense or any other linguistic element-so that half the items represented a structure with two specific events in a temporal succession, i.e., T1-T2: 'The kidnapper threatened them with his gun. The hostages panicked'; the other half expresses two events in a generic time scenario, where there are no elements that expressly define a temporal factor -T1: 'Camila suffers from tooth sensitivity. She avoids having food or drinks that are too cold or too hot. Table 1 shows examples of the items used in each one of the conditions evaluated.

Table 1. Examples of items by condition in Experiment 1.

\begin{tabular}{|c|c|c|c|}
\hline $\begin{array}{l}\text { Type of } \\
\text { relation }\end{array}$ & Structure & Connective & Item \\
\hline \multirow[t]{4}{*}{ Causal } & \multirow[t]{2}{*}{ Consecutive } & Absent & $\begin{array}{l}\text { The kidnapper threatened them with his gun, } \\
\text { the hostages panicked. } \\
\text { [El secuestrador los amenazó con su arma, } \\
\text { los rehenes entraron en pánico.] } \\
\text { Did the gun scare the hostages? } \\
\text { [¿El arma les generó miedo a los rehenes?] }\end{array}$ \\
\hline & & Present & $\begin{array}{l}\text { The kidnapper threatened them with his gun, } \\
\text { so the hostages panicked. } \\
\text { [El secuestrador los amenazó con su arma, } \\
\text { entonces los rehenes entraron en pánico.] }\end{array}$ \\
\hline & \multirow[t]{2}{*}{ Causal } & Absent & $\begin{array}{l}\text { The hostages panicked. The kidnapper } \\
\text { threatened them with his gun. } \\
\text { [Los rehenes entraron en pánico. El } \\
\text { secuestrador los amenazó con su arma.] }\end{array}$ \\
\hline & & Present & $\begin{array}{l}\text { The hostages panicked, because the } \\
\text { kidnapper threatened them with his gun. } \\
\text { [Los rehenes entraron en pánico porque el } \\
\text { secuestrador los amenazó con su arma.] }\end{array}$ \\
\hline $\begin{array}{l}\text { Counter- } \\
\text { causal } \\
(\text { Fillers })^{5}\end{array}$ & Adversative & Absent & $\begin{array}{l}\text { Catalina works many hours a day. She gets } \\
\text { home with energy to do the cleaning. } \\
\text { [Catalina trabaja muchas horas por día. } \\
\text { Llega a su casa con energía para limpiar.] } \\
\text { Does Catalina's job make her feel like not } \\
\text { cleaning her house? } \\
\text { [¿El trabajo de Catalina le saca las ganas de } \\
\text { limpiar en su casa?] }\end{array}$ \\
\hline
\end{tabular}

${ }^{5}$ In experimental psycholinguistics, it is common to use experimental condition items as fillers or distractors, in cases where complex designs are used. In this research, counter-causal factors work as fillers for causal ones. 
Volume 15 - Número 2 - ago/dez de 2020

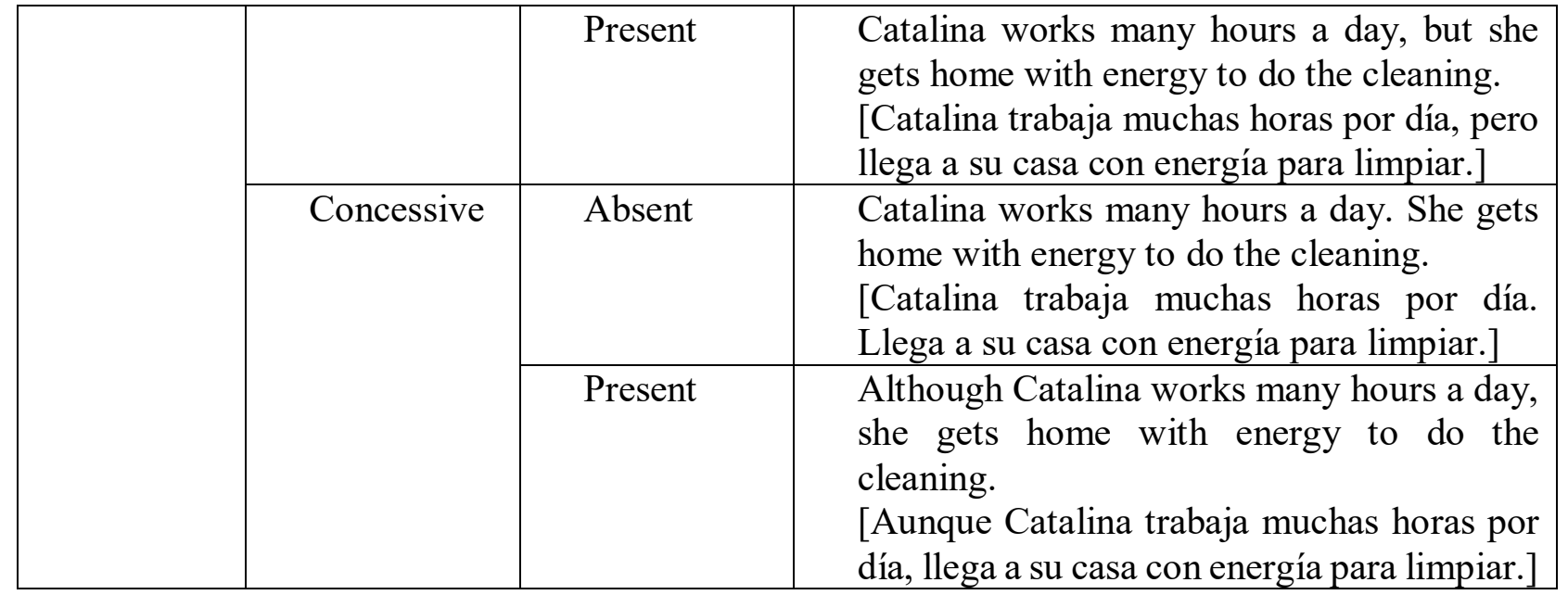

\subsubsection{Procedure}

The tasks were designed and administered in SuperLab 4.0. We presented first the complete sentence. After reading it, the participants pressed the space bar and the comprehension question appeared. There was no time restriction at all. Accuracy, items reading time (IRT) and task resolution or response time (RRT) were evaluated. The task was administered individually.

In every case, the instructions were provided in writing on a PC screen and verbally by the evaluator. After each instruction, participants were provided with an example to practice so as to verify that they had understood the exercise.

The proposed design was a Confounded Factorial Design $2 \times 2 \times 2$ with counterbalanced lists (KIRK, 2009), where schooling of subjects, order in the relation and connective were the factors used.

Each list of items had a total of 20 items: 10 were causal target items and 10 were counter-causal that worked as fillers. Also, two distractors were introduced as fixed items at the beginning of the set, and were then discarded, so that the timing was not affected by factors as getting used to the task. The rest of the items were presented in random order.

Participants were to press the spacebar to see the text written in black letters on a white screen. They would then read it at their own pace, and press the spacebar again to see the question about the text. In every case, it was a yes/no question below the text that was still displayed on screen, also written in black letters, but highlighted in bold italics. Texts remained on the screen to avoid extra cognitive cost due to memory demands. The question was intended to make explicit the mental representation of a causal relation, which may coincide with the item or not. Therefore, the causal items would correspond to a 'yes', while the counter-causal items would correspond to a 'no', thus balancing out the adequate response types. Participants had the option of not answering, if they considered that they did not know how to respond or they were unable to respond only with 'yes' or 'no', and could press the spacebar.

\subsection{Results}

Statistical analysis was performed with SPSS. First, we conducted an exploratory analysis to detect outliers and clean up the database. The decision was to use an outlier detection method that took into account the sample size in order to define a cut-off score to classify outliers (COUSINEAU; CHARTIER, 2010; THOMPSON, 2006). In no case more than 6\% of the total number of cases was eliminated, and outliers were always replaced by the mean by 
Volume 15 - Número 2 - ago/dez de 2020

subject by condition (RATCLIFF, 1979, 1993) ${ }^{6}$. Besides, before starting statistical testing with ANOVA, a process of logistic transformation (WOODS et al., 1986) was conducted on the response type measure (adequate or inadequate) to treat it a continuous variable.

Initially, in order to detect main effects and interactions in connection with the variables being studied, a full factorial analysis was conducted, using a between-subject factor -schooling level (low/ high) -and two within-subject factors: order (usual or reversed) of the causal relation, and connective (presence or absence of a connective).

Regarding response accuracy, there was a main effect of connective $(F(1,37)=5.75$; $\mathrm{p}<.022)$. Regarding IRT, there was a main effect of schooling level $(\mathrm{F}(1,37)=28.50 ; \mathrm{p}<.000)$ and the interaction ORDER*CONNECTIVE $(\mathrm{F}(1,37)=6.03 ; \mathrm{p}<.019)$ was statistically significant. Regarding RRT, however, there was a main effect of connective $(\mathrm{F}(1,37)=14.27 ; \mathrm{p}<.001)$. In addition, the latter showed significant interactions with the other within-subject factor: ORDER *CONNECTIVE $(\mathrm{F}(1.37)=7.58 ; \mathrm{p}<.009)$. The triple interaction failed to achieve significance: ORDER *CONNECTVE*SCHOOLING $(\mathrm{F}(1,37)=3.87 ; \mathrm{p}<.057)$.

Later, we conducted specific analyses of variance (ANOVA), relevant to this paper. In each subject group: 1) without connective in iconic order vs. without connective in reversed order; 2) without connective in iconic order vs. with connective 'so'; 3) without connective in the reversed order vs. with connective 'because'. In every case, we calculated F1 (by subjects) and F2 (by items) in order to be able to adequately project the results (CLARK, 1973).

Tables 2 and 3 show means and SDs for both subject groups under every condition.

Table 2. Means and Standard deviation for condition without connective.

\begin{tabular}{|c|l|l|l|l|l|}
\hline & & $\begin{array}{l}\text { Acuracy } \\
\%\end{array}$ & $\begin{array}{l}\text { Accuracy } \\
\text { TLog }\end{array}$ & IRT(SD)(ms) & RRT(SD)(ms) \\
\hline \multirow{2}{*}{ HS } & Iconic & 96,9 & $5,37(2,86)$ & $4176,60(1199,88)$ & $4470,89(1237,23)$ \\
\cline { 2 - 6 } & Reversed & 90,7 & $4,40(3,17)$ & $4856,86(1404,44)$ & $5905,67(2532,44)$ \\
\hline \multirow{2}{*}{ LS } & Iconic & 91,2 & $4,63(3,12)$ & $5138,55(1527,17)$ & $4694,64(1466,28)$ \\
\cline { 2 - 6 } & Reversed & 93,7 & $4,69(3,01)$ & $6589,04(2489,49)$ & $4736,62(1584,41)$ \\
\hline
\end{tabular}

HS= High Schooling; LS= Low Schooling; ms=miliseconds; TLog=logistic transformation of proportions; $\mathrm{IRT}=$ mean reading time; $\mathrm{RRT}=$ mean response time; $\mathrm{SD}=$ Standard deviation.

Table 3. Means and Standard deviation for condition with connnective.

\begin{tabular}{|c|l|l|l|l|l|}
\hline & & $\begin{array}{l}\text { Accura } \\
\text { cy\% }\end{array}$ & $\begin{array}{l}\text { Accuracy } \\
\text { TLog }\end{array}$ & IRT(SD)(ms) & RRT(SD)(ms) \\
\hline \multirow{3}{*}{ HS } & "So" & 97,4 & $5,92(2,60)$ & $4613,11(1436,89)$ & $4715,04(1884,09)$ \\
\cline { 2 - 6 } & "Because" & 99,1 & $6,84(2,03)$ & $3856,86(852,50)$ & $3225,35(891,57)$ \\
\hline \multirow{3}{*}{ LS } & "So" & 93,8 & $5,72(2,92)$ & $6560,02(2519,94)$ & $4517,26(2366,48)$ \\
\cline { 2 - 6 } & "Because" & 93,3 & $4,71(3,52)$ & $5647,30(1939,00)$ & $4071,54(1825,86)$ \\
\hline
\end{tabular}

HS= High Schooling; LS= Low Schooling; ms=miliseconds; TLog= logistic transformation of proportions; IRT= mean reading time; $\mathrm{RRT}=$ mean response time; $\mathrm{SD}=\mathrm{Standard}$ deviation.

Regarding response accuracy, neither of the two groups showed a statistically significant difference. Regarding IRT, F2 was significant in both cases, unlike F1. Regarding RRT, in the high schooling group, the contrast proved significant in favor of the iconic order $(F 1(1,22)=7.51 ; p<.012 ; F 2(1,9)=22.23 ; p<.001)$; but that was not the case in the low schooling group.

\footnotetext{
${ }^{6}$ It is considered that this analysis can eliminate between 1 and $10 \%$ of the total sample data.
} 
The analysis of accuracy did not show statistically significant differences between iconic items with and without connective 'so' in any of the subject groups. The IRT values showed significant contrasts only for F2 in both groups. RRT comparisons were not statistically significant in any case.

Regarding comparisons in reversed order without connective and with 'because', statistically significant differences appeared in the three measures evaluated for the high schooling group, but none were significant for the low schooling group. For accuracy, in the high schooling group: $F(1,22)=16.50 ; p<.001$. For IRT: $F 1(1,22)=6.43 ; p<.018 ; F 2(1,9)=$ $57.59 ; \mathrm{p}<.000)$. For RRT: F1 $(1,22)=22.92 ; \mathrm{p}<.000 ; \mathrm{F} 2(1,9)=113.43 ; \mathrm{p}<.000)$.

Lastly, we compared groups according to schooling level. Regarding accuracy, only the condition with 'because' showed statistically significant differences $(F(1,38)=5.68$; $\mathrm{p}<.022)$. Regarding IRT, several contrasts were significant. Both conditions - without connective in iconic order $(\mathrm{F} 1(1,38)=5.16 ; \mathrm{p}<.029 ; \mathrm{F} 2(1,18)=11.86 ; \mathrm{p}<.002)$ and in reversed order $(\mathrm{F} 1(1,38)=7,68 ; \mathrm{p}<.009 ; \mathrm{F} 2(1,18)=25,48 ; \mathrm{p}<.000)$ — showed significant differences. In the case of conditions with connective, all of the contrasts were statistically significant: with 'so' $(F 1(1,38)=9.40 ; p<.004 ; F 2 .(1,18)=23.06 ; p<.000)$ and with 'because' $(F 1(1,38)=13.86$; $\mathrm{p}<.001 ; \mathrm{F} 2(1,18)=29.22 ; \mathrm{p}<.000)$. Regarding RRT, no contrasts were statistically significant.

\subsection{Discussion}

We will start by reminding that the purpose of this experiment was to analyze if there were differences between two subject groups with different formal schooling levels, under the assumption that this factor would introduce different reading strategies in the two groups. We particularly observed whether the intervention of connectives, as semantic processing instructions, had a differentiating effect. We expected to find that a) the reversed order [effect][cause], by breaking the iconicity principle, would impose a processing difficulty that would be evidenced more clearly in the low schooling group; and b) the insertion of a connecting particle would facilitate processing in both groups, but it would be more necessary for subjects with weaker reading skills, i.e., in the low schooling group.

Regarding the effect of inversion of the iconic order (see Materials), we observed that, in general, we found a more marked impact in high schooling subjects and a greater effect on processing time than on accuracy. Even though the trend towards causality presented in its iconic format (see Materials) is maintained in both groups, it is likely to have a greater intragroup variation -with greater dispersion (SD)- in subjects in the low schooling group. This could explain the absence of significant differences. In future eperiments, we should verify if with a more homogeneous group this result holds or the data should be explained in another way.

Notwithstanding this fact, the pattern does not seem to be consistent. In this sense, the mere iconic order reversal does not present a significant obstacle to adequate comprehension when the reader has to process familiar information. This was reflected in the off-line measures of response accuracy, regardless of schooling level. However, it does seem to present an obstacle during on-line processing, which is reflected in IRT and RRT processing times.

Regarding the effect of the insertion of an explicit semantic marker -connectives 'so' and 'because'-, we can say that our initial prediction is partially verified. There is, in fact, a greater effect in the cases where causal relations are in reversed order, but the impact was statistically higher for the high schooling group than for the low schooling group.

Finally, it is essential to analyze the contrasts between both groups. It is worth mentioning that we observed that the edge pattern in favor of the high schooling subjects is concentrated around reading times, but there are just specific, small advantages regarding accuracy measures and show no advantages in response times. These results are susceptible of 
being analyzed in connection with greater dispersion in the low schooling group. In contrast, when it comes to reading times, the high schooling group shows a significant difference compared to the low schooling group, with consistently shorter times in all conditions. We believe that this finding is attributable, to a large degree, to the difference in general reading skills between both groups, which is definitely affected by schooling level, whereas reading training, if only due to exposure frequency to written text, is dependent upon years of formal schooling. These data, however, require a distinction between reading proficiency -in terms of basic reading processes, linked to decoding more than comprehension- and complex text/ discourse comprehension processes, among which we can mention semantic relations processing. These data, on the other hand, also divide reading skills from 'discipline expertise' in readers, i.e., their expert handling of specific information. To the extent that information familiarity remains a constant, reading processes become more automatic, which seems clearly dependent upon schooling level, but this is not the case with higher order comprehension processes. In these cases, texts seem to require the same linguistic conditions: regardless of the readers' schooling level, causal relations in iconic order and explicit semantic markers (connectives) favor comprehension in all cases.

In order to be more specific and complete the findings discussed herein, in Experiment 2 , we intend to verify what happens when we experimentally manipulate type of information for a high schooling level subject group.

\section{Experiment 2}

In order to propose another way to analyze how reader's prior knowledge is involved in the comprehension process, we conducted a second experiment, considering the type of information -everyday vs. technical- for the same subject group.

We considered that text comprehension processes are based not only on the use of explicit linguistic markers, but fundamentally on reader's prior knowledge to generate expectations during text/discourse processing (BRINER et al., 2011; COZJIN et al., 2011; DERY; KOENIG, 2015; DRENHAUS et al., 2014; GRAESSER, 1981; KAMILSKI et al., 2008; METUSALEM et al., 2016; MURPHY; MEDIN, 1985; NOORDMAN et al., 2014). We assume that any possible semantic relation comprehension pattern applied to texts/ discourse depends, to a large extent, on the conceptual organization of our world knowledge. Our world knowledge is represented and organized in our minds in certain ways. For instance, time and cause conceptual relations, which seem to respond to basic structures with certain characteristics, such as iconicity and cause-effect order seem to condition or influence our experience of the world events and their interpretation (BOSCH et al., 2018; FENKER et al., 2005; MURPHY; MEDIN, 1985; NOORDMAN; VONK, 1998; SANDERS, 2005). In this sense, when we analyze semantic relation comprehension in discourse, the process varies depending on whether we have those relations stored as part of our world knowledge (e.g., water boils because it reaches a given temperature), versus those cases for which we do not have that relation represented beforehand (e.g., a parasite causes a certain organic imbalance). In the former case, we can speak of comprehension of a causal relation that, in general terms has already been built/represented and stored, whereas in the latter, we should talk about the building of new causal relations, which could in the future be represented and stored. This seems the basic process to generate learning from texts.

The main purpose of this experiment is to analyze the resulting processing pattern, after manipulation of type of information (familiar vs. technical information). We also intend to evaluate the ways in which this general pattern is linked to specific variables, such as causal relation order or connective type. To us 'familiar' or 'everyday' information is the information that is part of the general world knowledge, at least in a given cultural/linguistic community. 
Conversely, we consider that 'technical knowledge' entails specific information from one area of scientific or specialized knowledge, handled by a restricted group of experts, and is not usually taught as part of mandatory educational syllabuses.

Within this framework, our initial prediction is that, assuming that the organization of stored causal relations follows the pattern [cause]-[effect] (BOSCH et al, 2018; NOORDMAN;VONK, 1998; SANDERS, 2005; ZUNINO, 2014), the presentation of reversed causal relations, i.e., [effect]-[cause], in technical items in cases where the reader is unable to involve prior knowledge, will mean a processing difficulty that will only be overcome with the presence of a connective, as the only semantic instruction that the reader can use.

\subsection{Method}

\subsubsection{Participants}

This experiment was conducted with the same subjects who participated in Experiment 1 in the high schooling group. The organization of the participants was the same. Data was obtained from 23 high schooling level subjects.

\subsubsection{Materials}

The items presented two clauses; in condition number 1 -no connective present-, there are two sentences, while in condition number 2 -with a connective present-, the two clauses are part of the same sentence. Each text is followed by a question with this pattern 'Does $A$ generate $B$ ?'

The temporal variable and grammar considerations were identical to Experiment 1.

Regarding the distinction between familiar items and technical items, we call familiar items those texts that express, narrate or describe situations or events from everyday life, which are therefore known to the participant and can be analyzed by involving their world knowledge in the comprehension process. Technical items, in term, are texts that express situations or events that are not known to the participants because they are part of very specific knowledge domains from certain scientific disciplines, such as astrophysics, quantum physics, geology, astronomy, genetics, or lesser known specialties within chemistry, medicine or biochemistry. None of the participants had specific knowledge in these areas.

In all cases, the items extension -number of words- was controlled. The result of this design was: items have between 12 and 18 words; familiar items have a mean of 14.3 words per item, while technical items have a mean of 19.5 words per item. All questions have between 7 and 12 words; mean for familiar items was 9.4 words per questions, and mean for technical items was 12.4 words per question.

Among technical items, the number of lexemes or technical phrases ${ }^{7}$ was controlled: all of them have between 2 and 4 technical words or phrases (mean: 3 per item).

Table 4. Examples of items by condition in Experiment 2.

\begin{tabular}{|l|l|l|l|}
\hline $\begin{array}{l}\text { Type of } \\
\text { information }\end{array}$ & Order & Connective & Item \\
\hline Familiar & Iconic & Absent & $\begin{array}{l}\text { Camila suffers from tooth sensitivity. She } \\
\text { avoids having too cold or too hot food and } \\
\text { drinks. }\end{array}$ \\
\hline
\end{tabular}

${ }^{7}$ These are lexemes or nominal phrases that belong to the lexical fields or jargons corresponding to the specific disciplines considered to be part of the technical items. Thus, "elliptical shape", for instance, is considered a unit, just as "perigee". 
Volume 15 - Número 2 - ago/dez de 2020

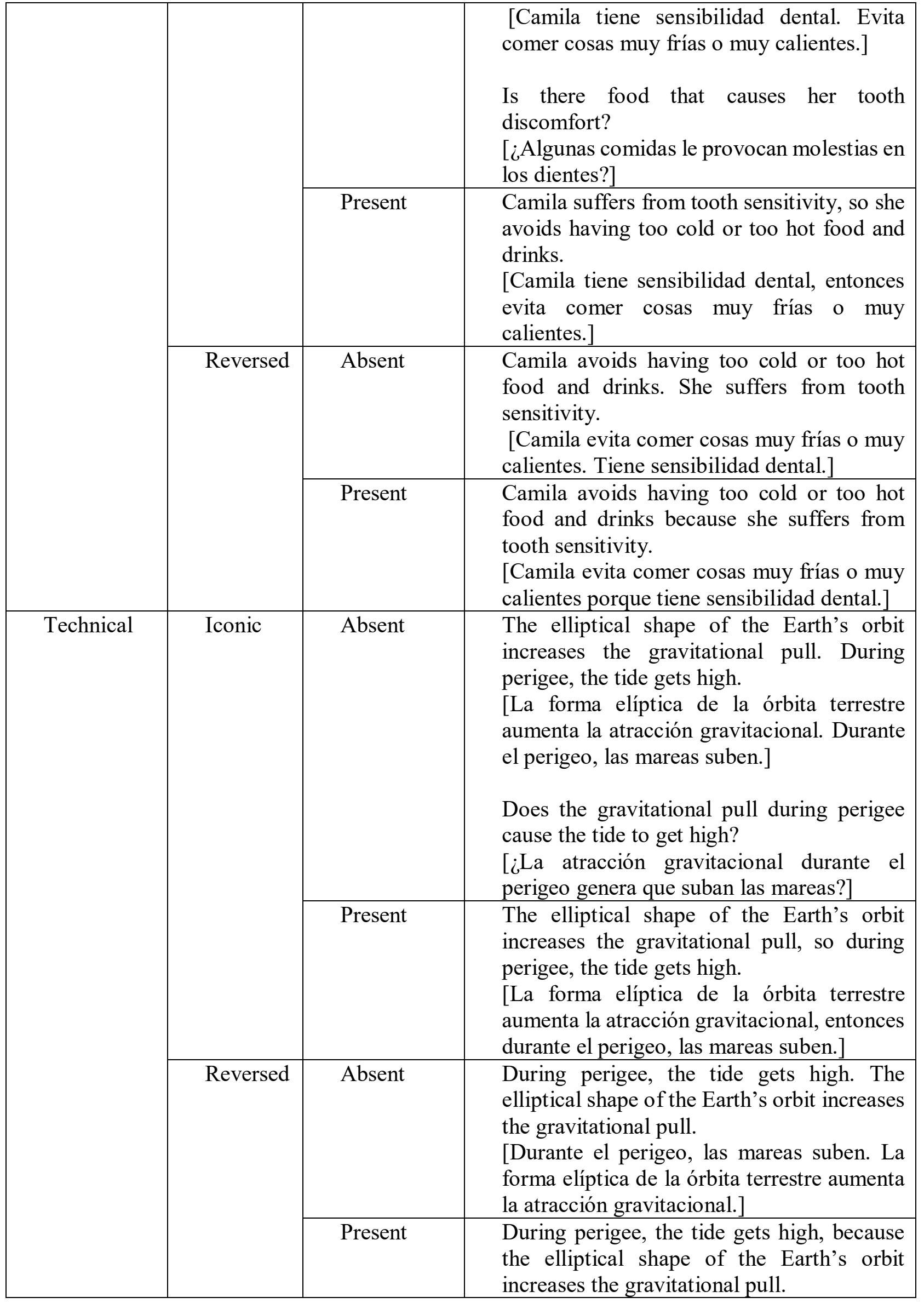


Volume 15 - Número 2 - ago/dez de 2020

\begin{tabular}{|l|l|l|}
\hline & & $\begin{array}{l}\text { [Durante el perigeo, las mareas suben, } \\
\text { porque la forma elíptica de la órbita terrestre } \\
\text { aumenta la atracción gravitacional. }\end{array}$ \\
\hline
\end{tabular}

\subsubsection{Procedure}

The items presentation procedure was the same as in Experiment 1. We used a Confounded Factorial Design $2 \times 2 \times 2$ with counterbalanced lists, including 40 items per list, 20 are familiar items and 20 are technical items. In each group, 10 items present a causal relation and the other 10, which act as fillers, a counter-causal relation.

\subsection{Results}

Statistical analysis was performed with SPSS. The outlier detection process was the same as in Experiment 1. For no condition or measure did we eliminate more than $6 \%$ of the data. Also, before starting analysis of variance (ANOVA), we conducted the same process of logistic transformation as in Experiment 1 for response accuracy measure.

Initially, in order to detect main effects and interactions, a full factorial analysis was conducted with type of information (familiar and technical) as an between-subject factor, and two within-subject factors, namely order (usual or reversed) of the causal relation, and connective (with and without a connecting particle present). We will only present the data corresponding to significant main effects and interactions.

Regarding response accuracy, there was main effect for ORDER $(F(1,44)=8.37$; $\mathrm{p}<.006)$, CONNECTIVE $(\mathrm{F}(1,44)=48.05 ; \mathrm{p}<.000)$ and for TYPE OF INFORMATION $(\mathrm{F}(1,44)=61.43$; $\mathrm{p}<.000)$. There were several significant interactions: order*type of information $(\mathrm{F}(1,44)=7.93$; $\mathrm{p}<.007) ; \quad$ CONNECTIVE*TYPE OF INFORMATION $(\mathrm{F}(1,44)=5.36 ; \mathrm{p}<.025)$; ORDER *CONNECTIVE*TYPE OF INFORMATION $(\mathrm{F}(1,44)=6.64 ; \mathrm{p}<.013)$. Regarding IRT, there was main effect for CONNECTIVE $(\mathrm{F}(1,44)=20.93 ; \mathrm{p}<.000)$ and TYPE OF INFORMATION $(\mathrm{F}(1,44)=68.65 ; \mathrm{p}<.000)$. Additionally, we also observed several significant interactions: CONNECTIVE* TYPE OF INFORMATION $(\mathrm{F}(1,44)=9.34 ; \mathrm{p}<.004)$ and ORDER *CONNECTIVE* TYPE OF INFORMATION $(\mathrm{F}(1,44)=13.58 ; \mathrm{p}<.001)$. Regarding RRT, there was main effect for CONNECTIVE $(\mathrm{F}(1,44)=25.71 ; \mathrm{p}<.000)$ and for TYPE OF INFORMATION $(\mathrm{F}(1,44)=71.50 ; \mathrm{p}<.000)$. The ORDER *CONNECTIVE interaction was close to having significance $(F(1,44)=3.77 ; p<.059)$. Also the CONNECTIVE*TYPE OF INFORMATION $(\mathrm{F}(1,44)=8.42 ; \mathrm{p}<.006)$ and ORDER ${ }^{*}$ CONNECTIVE*TYPE OF INFORMATION $(\mathrm{F}(1,44)=15.43 ; \mathrm{p}=.000)$ interactions were significant.

Later, we conducted specific comparisons relevant to this paper, by item group familiar and technical-, as follows: 1) causal without connective in the usual order vs. causal without connector in the reversed order; 2) causal without connective in the usual order vs. causal with 'so'; 3) causal without connective in the reversed order vs. causal with 'because'. Tables 5 and 6 show mean and standard deviation (SD) data for all conditions.

Table 5. Means and Standard deviation for condition without connective.

\begin{tabular}{|c|c|c|c|c|c|}
\hline & & $\begin{array}{l}\text { Accurac } \\
\mathrm{y} \%\end{array}$ & $\begin{array}{l}\text { Accuracy } \\
\text { TLog }\end{array}$ & IRT(SD)(ms) & RRT(SD)(ms) \\
\hline \multirow{2}{*}{ Familiar } & Iconic & 96,9 & $5,37(2,86)$ & $4176,60(1199,88)$ & $4470,89(1237,23)$ \\
\cline { 2 - 6 } & Reversed & 90,7 & $4,40(3,17)$ & $4856,86(1404,44)$ & $5905,67(2532,44)$ \\
\hline \multirow{2}{*}{ Technical } & Iconic & 68,6 & $1,11(1,74)$ & $9548,04(3016,92)$ & $16923,04(7811,69)$ \\
\cline { 2 - 6 } & Reversed & 51,6 &, $21(2,03)$ & $7339,59(2498,29)$ & $13085,46(7887,73)$ \\
\hline
\end{tabular}


Volume 15 - Número 2 - ago/dez de 2020

$\mathrm{TLog}=$ logistic transformation of proportions; $\mathrm{IRT}=$ mean reading time; $\mathrm{RRT}=$ mean response time; $\mathrm{SD}=\mathrm{Standard}$ deviation.

Table 6. Means and Standard deviation for condition with connective.

\begin{tabular}{|c|l|l|l|l|l|}
\hline & & Accuracy\% & $\begin{array}{l}\text { Accuracy } \\
\text { TLog }\end{array}$ & IRT(SD)(ms) & RRT(SD)(ms) \\
\hline \multirow{2}{*}{ Familiar } & "So" & 97,4 & $5,92(2,60)$ & $4613,11(1436,89)$ & $4715,04(1884,09)$ \\
\cline { 2 - 6 } & "Because" & 99,1 & $6,84(2,03)$ & $3856,86(852,50)$ & $3225,35(891,57)$ \\
\hline \multirow{2}{*}{ Technical } & "So" & 95,2 & $5,14(2,89)$ & $6281,12(1702,35)$ & $8128,61(3412,73)$ \\
\cline { 2 - 6 } & "Because" & 76,1 & $2,15(2,72)$ & $7775,47(2833,44)$ & $12927,96(7437,13)$ \\
\hline
\end{tabular}

$\mathrm{TLog}=$ logistic transformation of proportions; IRT= mean reading time; RRT= mean response time; $\mathrm{SD}=$ Standard deviation.

For order factor, none of the contrasts was statistically significant for familiar items. In the technical items group, on the contrary, IRT was statistically significant in favor of the iconic order $(\mathrm{F} 1(1,22)=10.36 ; \mathrm{p}=.004 ; \mathrm{F} 2(1,9)=52.46 ; \mathrm{p}=.000)$. For accuracy and RRT, F1 came close to becoming significant, but F2 did not.

The comparisons between items in iconic order, with and without connective, did not show statistically significant results in the familiar items group. In the technical items group, we found a statistically significant comparison for response accuracy $(F(1,22)=22.09 ; p=<.000)$ and for the two time measures, in favor of the condition with connective: $\operatorname{IRT}(\operatorname{F1}(1,22)=20.36$; $\mathrm{p}<.000 ; \mathrm{F} 2(1,9)=140.82 ; \mathrm{p}<.002)$ and $\operatorname{RRT}(\mathrm{F} 1(1,22)=24.79 ; \mathrm{p}<.000 ; \mathrm{F} 2(1,9)=63.12 ; \mathrm{p}<.000)$.

The comparison between items in reversed order with and without a connective, in the familiar item group was statistically significant for all measures, in favor of the condition with connective: accuracy in the responses $(\mathrm{F}(1,22)=16.50 ; \mathrm{p}<.001)$; SRT $(\mathrm{F} 1(1,22)=6.43 ; \mathrm{p}<.018$; $\mathrm{F} 2(1,9)=57.59 ; \mathrm{p}<.000)$; TRT $(\mathrm{F} 1(1,22)=22.92 ; \mathrm{p}<.000 ; \mathrm{F} 2(1,9)=113.43 ; \mathrm{p}<.000)$. For the technical item group, the only statistically significant contrast was found for accuracy, in favor of the condition with 'because': $F(1,22)=6.91 ; p<.015$.

\subsection{Discussion}

First of all, we should remember that the purpose of this experiment is to analyze the processing pattern that arises from the manipulation of the 'type of information' factor, i.e., familiar or technical information. We also evaluated how this general pattern is conditioned by specific variables, such as causal relation order or type of connective. Within this framework, our hypothesis was that, assuming that the organization of the stored causal relations is [cause][effect] (NOORDMAN; VONK, 1998; SANDERS, 2005; ZUNINO, 2014), the comprehension of reverted causal relations, [effect]-[cause], in the technical items, would entail a processing difficulty that could only be overcome by the presence of an explicit semantic marker (connective).

Firstly, it is possible to see that the technical item set shows a pattern that is consistently different from the familiar item group. Our results show that the type of information variable introduces a decisive bias and not being able to resort to prior knowledge during comprehension of the fragments substantially modifies performance patterns.

Regarding the effect of order, the first key point to observe is the random pattern in responses corresponding to the technical items in absence of an explicit semantic marker (51,6\% of correct responses). Both items presented in iconic order and those presented in reversed order lack a response accuracy pattern: it is not possible to confirm any consistent semantic processing. In this sense, processing time analysis becomes more complex, and the results obtained do not enable us to clearly establish which underlying process is being 
measured. For instance, is a significantly lower reading speed for technical items an undeniable piece of data proving that the iconic order provides an advantage, when the responses are comparable to random responses? We believe that the answer is no, and, consequently, time measures in the cases where we cannot establish a clear semantic processing pattern, may not reflect the underlying process that we want to analyze.

However, the fact that readers cannot process the semantic relations with any degree of certainty, whenever it is impossible for them to resort to prior knowledge in the absence of a connective, strongly supports our initial prediction: prior knowledge is a key factor for comprehension, and in its absence, linguistic knowledge not only facilitates comprehension but becomes an indispensable element for the process to take place. However, the results force us to review our initial hypothesis: without prior knowledge and without an explicit semantic marker, not only reversed order relations show this potential processing difficulty/impossibility. Under these conditions, the syntagmatic order of the clauses does not constitute a strong enough clue either, and the category 'iconic order'/'reversed order' loses ground. There is no iconic, unmarked and expected order in unknown relations, and the expected order would arise from our own conceptual organization based on our representation of the world.

The analysis of the impact of the show an effect on the response accuracy measures: the presence of a connective differentiates the response pattern from a random distribution in the technical items. As for relations in the iconic order, it is noticeable assimilated to the order found for familiar items. There is also a significant impact on time measures: it shortens both the reading process and the response time, but it does not have a statistically significant effect in the case of technical items in reversed order, something that was verified for familiar items in reversed order. It is worth underscoring that the insertion of a connective helps overcome one of the two obstacles that our texts present. Connectives either eliminate the difficulty related to order, or revert the difficulty arising from the impossibility of resorting to prior knowledge, but it does not eliminate both obstacles at the same time.

Even though it is not possible to assert the exact characteristics of the conceptual organization of that knowledge, we can say that notions such as iconicity and continuity (HAIMAN, 1983; MURRAY, 1997; ZUNINO, 2014) seem to show feasible criteria for such organization, especially in the causal dimension. The comparison of text processing between familiar and technical information enables us to support the idea that our world knowledge could show a causal structure. That is, a causal axis that not only affects the processing of known information, but also imposes certain restrictions or guidelines for the causal organization of new information. Along these lines, the analysis of processing patterns, when it comes to 'building' new causal relations based on texts that contain unknown information, can be a valid way of inferring a possible specific form of that organization. The findings of this experiment show that the [cause]-[effect] structure seems to be the default structure and, therefore, the creation and storage of new relations is easier when the text follows that iconicity.

The above mentioned points suggest that our general linguistic knowledge and a proper handling of semantic information provided by certain linguistic constructions and lexemes, such as connectives, are basic and fundamental elements for adequate text comprehension. Their role is so decisive that they can even eliminate the obstacle arising from the absence of prior knowledge and help the reader build complex semantic relations 'from scratch'. Explicit linguistic markers can be more or less vague from the semantic point of view-or even be absent in the cases of processing by default (ZUNINO, 2014; ZUNINO, 2016)-, to the extent that the reader can rely on prior knowledge to understand discourse. Otherwise, linguistic markers become indispensable for discourse comprehension, and without them, it is impossible to ensure semantic processing. 
Volume 15 - Número 2 - ago/dez de 2020

\section{General discussion}

First, we want to remind that the purpose of the two experiments discussed herein was to analyze the link between reading skills and prior knowledge, and the linguistic characteristics of texts, particularly regarding comprehension of causal relations. We analyzed the main effects and interactions between four key factors: formal schooling level, type of information, order in semantic relations, and presence or absence of connective. In each experiment, we considered response accuracy and processing times as dependent variables.

As was mentioned above, this paper is one more in a series of studies focusing on a broad range of questions that have sparked the interest of several authors (BEKER et al., 2017; BRINER et al., 2011; COZJIN et al., 2011; DERY; KOENIG, 2015; ELBRO; BUCHIVERSEN, 2013; FRANK et al., 2003; HAGOORT et al., 2004; KUPERBERG et al., 2006, MCNAMARA et al., 1996; MCNARAMA, 2001; MÜNTE et al., 1998; NOORDMAN; VONK, 1998; NOORDMAN et al., 2014; O'REILLY; MCNAMARA, 2007a,b; XIANG; KUPERBERG, 2015; SANDERS, 2005; ZUNINO, 2014; inter alia). That is: how do our mental representation of the world and our conceptual organization of that information come into play during text comprehension? How is this information linked to the information contained in the text and the reader's linguistic knowledge? How does this psycholinguistic evidence contribute to the comprehension of text-based learning processes?

One of the main points that can be derived from our data, and a key one when it comes to reflecting on pedagogic processes, is the dissociation between the effect of subjects' reading skills and readers' expertise or specificity of prior knowledge. Formal schooling seems to have a direct impact on the former factor, while the latter affects subjects with any schooling level, and casts its shadow on any learning process, regardless of schooling level, since it implies processing, conceptually organizing and storing new information, and not necessarily a new skill. These results are consistent with the ones discussed in other papers (MCNAMARA, 2001, O'REILLY; MCNAMARA, 2007a,b; LINDERHOLM et al, 2000; BEKER; JOLLES; VAN DEN BROEK, 2017). In this sense, we must bear in mind that these are very different issues in cognitive terms, but they are articulated in didactic terms in any educational process. In one case, this revolves around a process --a skill-- that is susceptible of being improved through training: both reading and text comprehension skills. In the other case, it has to do with the acquisition and conceptual organization of new knowledge. It involves new information which will be structured and stored in our declarative memory (NOORDMAN;VONK, 1998; RAITER, 2000; TULVING, 1972; VAN DEN BROEK; RAPP; KENDEOU, 2005), so that it can then be put at the service of a new cognitive process: comprehension, reasoning, creation, thought, in general, to subsequently scaffold new knowledge. Despite these apparent differences, there seem to be linguistic issues that must be necessary conditions for both processes to take place as successfully as possible. To us, this is the most important contribution of psycholinguistic evidence to education. For instance, it seems essential when it comes to creating teaching aids and materials that can boost learning possibilities. On the other hand, as was mentioned by LINDERHOLM et al. (2000), the panorama is a complex one and involves multiple variables interacting throughout the process. Along this line, this paper takes a step forward in the evaluation of triple interactions between text characteristics and reader traits. However, there is room to continue researching along these lines, for instance in the linkage between syntactic structure, type of semantic relationship and type of information presented in the texts (ZUNINO, 2017).

In other papers we have analyzed results that indicate that causality is a privileged semantic dimension vis-a-vis other meaning relations (ZUNINO; ABUSAMRA; RAITER, 2012; ZUNINO, 2014; ZUNINO, 2016). Causality seems to be a primitive conceptual organization factor, a ruling principle or formal/conceptual 'spine' around which new 
Volume 15 - Número 2 - ago/dez de 2020

information adapts to when it is stored (COZJIN; NOORDMAN; VONK, 2011; KUPERBERG; PACZYNSKI; DITMAN, 2011; LINDERHOLM et al., 2000; NOORDMAN; VONK, 1998; SANDERS, 2005; ZUNINO, 2014).

In order to specify and strengthen this evidence, this paper was also able to point out that: a) texts presenting causal relations in iconic order, i.e., [cause]-[effect], are easier to process; b) however, when it comes to information that is familiar to the reader, this is not a decisive factor impacting on comprehension; c) the presence of explicit semantic markersconnectives-, acting as processing instructions are facilitators, both for the reading process -on line - and the comprehension process -off line-, in all schooling levels; d) the presence of connectives is essential to successful semantic processing, whenever the reader is dealing with unknown information, and cannot make use of prior knowledge; in these cases, linguistic knowledge alone -as part of their reading skills, regardless of their individual degree of expertise on the topic-, will make information processing -and eventually, learning- possible.

Finally, it is worth highlighting that there are several limitations to this paper, which may lead to future research paths. First, this paper is limited to causal relations and analyzes just some linguistic constructions establishing causality. Future research should expand this horizon to other semantic dimensions and other constructions. On the other hand, it is essential to analyze how textual macro-structure and readers' expectations interact during semantic relation comprehension, by analyzing different text types and genres. Lastly, we believe that, like in some other papers that we have been working on (ZUNINO, 2017), it is necessary to explore the syntactic-semantic interface in text processing, i.e., analyze the link between syntactic structure and semantic information.

\section{Acknowledgement}

This research was possible thanks to the economic support offered by the Argentine scientific-technological system. On the other hand, we want to thank our anonymous reviewers for their careful reading and valuable feedback.

\section{References}

BEKER, K.; JOLLES, D.; VAN DEN BROEK, P. Meaningful learning from Texts: The construction of Knowledge Representations. In I. ESCUDERO; LEÓN, J. (eds.) Reading Comprehension in Educational Settings, Amsterdam: John Benjamins, 2017, p. 29-62

BOSCH, L.; SEGERS, E.; VERHOEVEN, L. Online processing of causal relations in beginning first and second language readers. Learning and Individual Differences, v. 61, p. 59-67, 2018.

BRINER, S.W.; VIRTUE, S.; KURBY, C.A. Processing Causality in Narrative Events: Temporal Order Matters. Discourse Processes, v. 49, n.1, p. 61-77, 2011.

CARON, J.; MICKO, H. C.; THURING, M. Conjunctions and the recall of composite sentences. Journal of Memory and Language, v. 27, p. 309-323, 1988.

COUSINEAU, D.; CHARTIER, S. Outliers Detection and Treatment: A review. International Journal of Psychological Research, v.3, n.1, p. 58-67, 2010.

COZIJN, R.; NOORDMAN, L.; VONK, W. Propositional Integration and World-Knowledge Inference: Processes in Understanding Because Sentences. Discourse Processes, v. 48, n.7, p. 475-500, 2011.

DEGAND, L.; LEFÈVRE, N., BESTGEN, Y. The impact of connectives and anaphoric expressions on expository discourse comprehension. Document Design, v.1, p. 39-51, 1999. DERY, J.E.; KOENIG, J.P. A Narrative-Expectation Based Approach to Temporal Update in Discourse Comprehension. Discourse Processes, v. 52, n.7, p. 559-584, 2015. 
Volume 15 - Número 2 - ago/dez de 2020

DRENHAUS, H.; DEMBERG, V.; KÖHNE, J.; DELOGU, F. Incremental and predictive discourse processing based on casual and concessive discourse markers: ERP studies on German and English. Proceedings of The Annual Meeting of the Cognitive Science Society, v. 36, p. 403-408, 2014.

ELBRO, C.; BUCH-IVERSEN, I. Activation of Background Knowledge for Inference Making: Effects on Reading Comprehension. Scientific Studies of Reading, v. 17, n. 6, p. 435-452, 2013.

FENKER, D.; WALDMANN, M.; HOLYOAK, K. Accesing casual relations in semantic memory, Memory and Cognition, v. 33, n. 6, p. 1036-1046, 2005.

FRANK, S.; KOPPEN, M.; NOORDMAN, L.; VONK, W. Modeling Multiple Levels of Text Representation. In F. SCHMALHOFER \& C.A. PERFETTI (eds). Higher level language processes in the brain: inference and comprehension processes. Mahwah, NJ: Erlbaum, 2007, p. 133-157

GERNSBACHER, M. A. Cognitive processes and mechanisms in language comprehension: The structure building framework. In G. H. BOWER (ed.) The Psychology of Learning and Motivation. New York: Academic Press, 1991, p. 217-263.

GOLDMAN, S.; GRAESSER, A.; VAN DEN BROEK, P. Narrative Comprehension, Causality, and Coherence. Essays in Honor of Tom Trabasso. London: Lawrence Erlbaum, 1999.

GRAESSER, A. Prose Comprehension Beyond the Word. Nueva York: Springer-Verlag, 1981.

GRAVETTER, F.; WALlnAU, L. Statistics for the Behavioral Sciences. Belmont: Wadsworth, 2009.

HABERLANDT, K. Reader Expectations in Text Comprehension. In LE NY, J. F.; KINTSCH, W. (eds.), Language and Comprehension. Amsterdam: North Holland, 1982, p. 239-250

HAGOORT, P.; HALD, L. A.; BASTIAANSEN, M. C. M.; PETERSSON, K. M. Integration of word meaning and world knowledge in language comprehension. Science, 304(5669), p. 438-441, 2004.

HAIMAN, J. Iconic and Economic Motivation. Language, v.59, p.781-819, 1983.

KAMILSKI, J.; SANDERS, T.; LENTZ, L. Coherence Marking, Prior Knowledge and Comprehension of Informative and Persuasive Texts: Sorting Things Out. Discourse Processes, v. 45: 323-345, 2008.

KENDEOU, P.; VAN DEN BROEK, P. The effects of prior knowledge and text structure on comprehension processes during reading of scientific texts. Memory and Cognition, v. 35, n. 7, p. 1567-1577, 2007.

KINTSCH, W. The role of knowledge in discourse comprehension construction-integration model. Psychological Review, n. 95, p. 163-182, 1988.

KINTSCH, W. Comprehension: A paradigm for cognition. NY: Cambidge University Press, 1988.

KIRK, R. E. Experimental design. In: MILLSAP, R.; A. Maydeu-Olivares, A. (eds.). Sage handbook of quantitative methods. Thousand Oakes, CA: Sage, 2009, p. 23-45.

KUPERBERG, G.; LAKSHMANAN, B.; CAPLAN, D.; Holcomb, P. Making sense of discourse: An fMRI study of causal inferencing across sentences. NeuroImage, v. 33, p. 343$361,2006$.

KUPERBERG, G.; PACZYNSKI, M.; DITMAN, T. Establishing Causal Coherence across Sentences: An ERP Study. Journal of Cognitive Neuroscience, v. 23, n. 5, p. 1230-1246, 2011.

LINDERHOLM, T.; EVERSON, M.; VAN DEN BROEK, P.; MISCHINSKI, M.; GITTENDEN, A.; SAMUELS, J. Effects of Causal Text Revisions on More-and-Less-Skilled 
Volume 15 - Número 2 - ago/dez de 2020

Readers' Comprehension of Easy and Difficult Texts. Cognition and Instruction, v. 18, n. 4, p. 525-556, 2000.

MARCUS, S.; CALUDE, A. Syntactic iconicity, within and beyond accepted principles. Revue Roumaine de Linguistique, v. 4, p. 19-44, 2010.

MCNAMARA, D. Reading both high-coherence and Low-Coherence Texts: Effects of Text sequence and Prior Knowledge. Canadian Journal of Experimental Psychology, v. 55, n.1, p. 51-62, 2001.

MCNAMARA, D.; KINTSCH, E.; SONGER, N.; KINTSCH, W. Are Good Texts Always Better? Interactions of Text Coherence, Background Knowledge, and Levels of Understanding in Learning From Text. Cognition and Instruction, v. 14, n. 1, p. 1-43, 1996.

MÜNTE, T, SCHILTZ; KUTAS, M. When temporal terms belie conceptual order, Nature, v. 395, n. 3, p. 71-73, 1998.

MURPHY, G.; MEDIN, D. The Role of Theories in Conceptual Coherence, Psychological Review, v. 92, n. 3, p. 289-316, 1985.

MURRAY, J. D. Connectives and narrative text: The role of continuity. Memory \& Cognition, v. 25, n. 2, p. 227-236, 1997.

NOORDMAN, L.; VONK, W. Memory-based processing in understanding casual information. Discourse Processes, v. 26, n. 2-3, p. 191-212, 1998.

NOORDMAN, L.; VONK, W.; COZJIN, R.; FRANK, S. Causal inferences and World Knowledge. In O'BRIEN, E.J.; COOK, A.E.; LORCH, R.F. (eds.). Inferences during reading. MA: Cambridge University Press, p. 260-289, 2014.

O'REILLY, T.; MCNAMARA, D. Reversing the Reverse Cohesion Effect: Good Texts Can Be Better for Strategic, High-Knowledge Readers. Discours Processes, v. 43, n. 2, p. 121-152, $2007 \mathrm{a}$.

O'REILLY, T.; MCNAMARA, D. The impact of Science Knowledge, Reading Skill and Reading Strategy Knowledge on More Traditional "High-Stakes" Measures of High School Students'Sciencie Achievement. American Educational Research Journal, v. 44, n. 1, p. 161196, $2007 b$.

RAITER, A. Las referencias (mentales) para establecer el significado lingüístico: conocimientos previos, memoria enciclopédica, sistema de creencias y sentido común. (Unpublished PhD Thesis Dissertation.) Facultad de Filosofía y Letras, Universidad de Buenos Aires, Buenos Aires, 2000.

RAITER, A. Lenguaje y sentido común. Las bases para la formación del discurso dominante. Buenos Aires: Biblos, 2003.

RATCLIFF, R. Group Reaction Time Distributions and an Analysis of Distribution Statistics.

Psychological Bulletin, v. 86, p. 446-461, 1979.

RATCLIFF, R. Methods for Dealing with Reaction Time Outliers. Psychological Bulletin, v. 114, v. 3, p. 510-532, 1993.

SANDERS, T. J.M. Coherence, Causality and Cognitive Complexity in Discourse. Proceedings/Actes SEM-05. First International Symposium on the Exploration and Modeling of Meaning, p. 105-114, 2005.

THOMPSON, G. An SPSS implementation of the nonrecursive outlier deletion procedure with shifting z score criterion (Van Selst \& Jolicoeur, 1994). Behavior Research Methods, v. 38, n. 2, p. 344-352, 2006.

TULVING, E. Episodic and Semantic Memory. En TUlVING, E.; DONALDSON, W. Organization of Memory. Nueva York: Academic Press, 1972.

VAN DEN BROEK, P.; RAPP, D.; KENDEOU, P. Integrating Memory-Based and Constructionist Processes in Accounts of Reading Comprehension. Discourse Processes, 39(2/3): 299-316, 2005. 
VAN DIJK, T.; KINTSCH, W. Strategies of Discourse Comprehension. New York: Academic Press, 1983.

VAN DIJK, T. La ciencia del texto. Un enfoque interdisciplinario. Barcelona: Paidós, 1992. VAN SILFHOUT, G.; EVERS-VERMEUL, J.; SANDERS, T. Connectives as Processing Signals: Hoe Students Benefit in Processing Narrative and Expository Texts. Discourse Processes, v. 52, n. 1, p. 47-76, 2015.

WOODS, A.; FLETCHER, P.; HUGHES, A. Statistics in Language Studies. Cambridge: Cambridge University Press, 1986.

XIANG, M.; KUPERBERG, G. Reversing Expectations during Discourse Comprehension. Language, Cognition and Neuroscience, v. 30 , n. 6, p. 648-672, 2015.

ZWAAN, R.; RADWANSKY, G. Situation Models in Language Comprehension and Memory. Psychological Bulletin, v. 123, p. 162-185, 1998.

ZUNINO, G.M.; ABUSAMRA, V.; RAITER, A. Causalidad: relación entre conocimiento de mundo y conocimiento lingüístico. Pragmalingüística, v. 20, p. 200-219, 2012.

ZUNINO, G. M. Procesamiento psicolingüístico de relaciones semánticas: causalidad y contracausalidad (Unpublished $\mathrm{PhD}$ Thesis Dissertation), Facultad de Filosofía y Letras, Universidad de Buenos Aires, 351 p., 2014.

ZUNINO, G.M. Comprensión y producción de causalidad y contracausalidad: distinciones en función del proceso subyacente y efectos de la escolarización formal. Onomázein, 34, 132$151,2016$.

ZUNINO, G. M.; ABUSAMRA, V.; RAITER. Causalidad, Iconicidad y Continuidad: efectos del conocimiento previo sobre el mundo durante la comprensión de relaciones causales Alfa: Revista de Lingüística, v.60, n.2, p. 261-285, 2016.

ZUNINO, G.M. Procesamiento de causalidad y contracausalidad: interacciones entre estructura sintáctica y conocimiento del mundo en la comprensión de relaciones semánticas. Revista Signos. Estudios de Lingüística, v. 50, n. 95, p. 472-491, 2017. 